\title{
Changing Paradigms: The Role of Translation in the Colonial and the Postcolonial Period
}

PRATIBHA KUMARI

\section{Abstract}

The paper looks at the problematic of postcolonial translation and the role of the translator amid the complexities of the discipline of Translation Studies. It begins by a brief genealogy of the field of translation and the development of Translation Studies as a separate field of study around 1970s. It lays emphasis on the role of translation in colonial times and turns to postcolonial translation theory in order to delineate the intricacies involved in these structures of analyses by engaging primarily with two essays titled History in Translation by Tejaswini Niranjana and Post-Colonial Writing and Literary Translation by Maria Tymoczko. It argues that owing to the intricate relationship between politics and translation, the role of the translator has undergone considerable change alongside the evolution of the discipline of Translation Studies. This role gets even more problematized when seen from the perspective of translation in the era of globalization.

Keywords: Translation Studies, Postcolonial Translation, Globalization, Politics.

Translation has always been an integral part of human history. It has played a significant role in the development of civilizations by facilitating cross-cultural interactions. It was only through translation that different linguistic cultures could interact with one another. From ancient to medieval and the modern times, its importance has only increased because it helped in expansion of the domain of knowledge about the existence and the particularities of cultures other than one's own. In a sense, it served the function of being a window to the world. G. J. V. Prasad has rightly argued: "Great civilizations 
are born in translation, because of translations" (Prasad 2010). In one of its earliest roles, translation worked as a tool that made communication possible amid cultures that used different languages. One cannot imagine the possibility of the functional trade roots in ancient times without the availability of translation. Megasthenes, the Greek explorer and ambassador to Selucas Nicator visited Patliputra (the capital of Mauryan Empire) around $300 \mathrm{BCE}$. His experiences in India led him to write the book Indica. This suggests that ancient and medieval societies have largely been multilingual and translation played a key role in the functioning of large empires as well as in the development of literature, arts and aesthetics. In modern times, there is probably no discipline which is not influenced by translation. Not just academics but fields like governance, legal studies, medical sciences, and scientific research all make extensive use of translation. One can visualize that the role of translation has evolved over time and it has become even more complex in the era of globalization.

Despite its long history of existence, translation was largely studied as a subsidiary branch of Comparative Literature or Linguistics. Translation Studies as a separate discipline in the academia is a recent phenomenon that dates back to late twentieth century. Even though the term Translation Studies was proposed as early as 1972 by the American translator James Holmes in the essay "The Name and Nature of Translation Studies", the discipline saw major theoretical developments in later works by Andrě Lefevere ${ }^{1}$ and Susan Bassnett $^{2}$. Prior to these developments, the theorization of translation largely dealt with the craft of translating from one language to another. This is expressed in essays by Etienne

\footnotetext{
${ }^{1}$ Refer to "Translation Studies: The Goal of the Discipline" (1978).

${ }^{2}$ See Literature and Translation, 1997
} 


\section{Pratibha Kumari}

Dolet $^{3}$ and Alexander Fraser Tytler ${ }^{4}$. These texts reinforce the primacy of original over the translated text. They also call for 'sense-to-sense' translation rather than literal translation. One can argue that the translator enjoyed little freedom in order to re-create the original in his translation. Translation was largely conceived as a secondary activity that aimed to approximate the original. Consequently, it always remains a zone of loss because approximation can never reach equivalence. Holmes's concept paved way for engagement with the problematic of translation and its reception. The discipline was radically revamped when Susan Bassnett outlined its scope in Translation Studies by arguing: It is "not merely a minor branch of comparative literary study, nor yet a specific area of linguistics, but a vastly complex field with many far reaching ramifications" (Bassnett 1980: 1). Translating from one language to another demands a thorough knowledge of both the source language as well as the target language. Given this connection between Translation Studies and Linguistics, Poststructuralism remained the centre of concern for translation theorists for a considerable period. Poststructuralist criticism undermined the earlier concepts of translation that sought the transference of the 'meaning' or 'essence' while translating one text into another language. Michael Foucault's essay "What is an Author?" (1969) snatched away the authority as well as superior status ascribed to the author. The essay denies the privilege of authority to a single author because a work of art is an outcome of the interplay between multiple factors like socio-political factors, material reality and the context within which the text is written. For Foucault, "the act of creation is in reality a series of complex processes" and the author is a "series of subjective positions, determined not

\footnotetext{
${ }^{3}$ Dolet, Etienne. "The Way to Translate from One Language to Another", 1540

${ }^{4}$ Tytler, Alexander Fraser. The Principles of Translation, 1797
} 
by any single harmony of effects, but by gaps, discontinuities, and breakages" (Gentzler 2010: 150). Derridean theory of Deconstruction engaged with the complex relationship between a text and its meaning(s). It took away the stability of structures and fixity of meanings. He argued for the play of signification that leads to multiplicity of meanings. For the first time, the original and the translation came on equal footing and the hierarchy between the author and the translator collapsed. This made translators to negotiate their relationship with the 'original' text which needs to be translated. With a text having multiplicity of meanings, how can one aim to 'carry over' or 'translate' the essence in a distinct language? The poststructuralist concept of the indeterminacy of language undermined the concepts of equivalence and translatability. Around 1980s, Translation Studies received a cultural dimension wherein culture became the central term around which discourses on translation evolved.

In 1990, Susan Bassnett and Andre Lefevere jointly wrote the book Translation, History and Culture. The introductory essay to the book was titled "The Cultural Turn in Translation Studies" that brought a paradigm shift in the discipline. Translation became a complex interaction between two cultures. This helped to broaden the narrow frameworks within which translation was studied so far. From its formalist phase, Translation Studies moved on to address the larger question of socio-cultural context. In regard to the 'cultural turn', Susan Bassnett argued that: a study of the processes of translation combined with the praxis of translating could offer a way of understanding how complex manipulative textual processes take place: how a text is selected for translation, for example, what role the translator plays in that selection, what role an editor, publisher or patron plays, what criteria determine the 
strategies that will be employed by the translator, how a text might be received in the target system (123).

This departure had a huge impact on the understanding of literature, culture and the role of translation in postcolonial situations. "Translation is not simply an act of faithful reproduction but, rather, a deliberate and conscious act of selection, assemblage, structuration and fabrication - and even, in some cases of falsification, refusal of information, counterfeiting, and the creation of secret codes" writes Aditya Kumar Panda in the essay titled "Politics and Translation". This is best exemplified by the way translation was used during the period of colonization. Translation and colonization worked in conjunction with one another across the globe. In fact, translation became a metaphor for the colony while European cultures enjoyed the superior status of being the original. In India, Sir Wiiliam Jones founded the Asiatic Society in 1784 that aimed at furthering the cause of the oriental research. It was considered important to know the orient in order to dominate the colony. For a similar purpose, Fort William College was established by Lord Wellesly in 1800 that specialized in Oriental studies. One of the significant translations to emerge in this period was Kalidasa's Abhijanasakuntalam that was translated as Sacontala by William Jones. The text was largely appropriated according to western aesthetics and didn't pay any heed to specificities of Indian culture. Initially, the flow of translation remained from east to west. The motivation was to know the orient as well as control the knowledge production about the cultural 'other'. However, by nineteenth century, texts were being translated from European languages to the native Indian languages. These translations served multiple functions. From the perspective of the colonizer, it became a means of displaying the superiority of western academia that was (in)famously 
boasted by Macaulay in "Minutes on Education" $(1835)^{.5}$ Mahashweta Sengupta argues that the colonial translations presented Indian texts as specimens of a culture that is "simple", "natural", "other-worldly", and "spiritual". For the elite and educated section of colonized natives, translation became a window to the world and also a tool to fight the European Imperialism. Social reformers made extensive use of inter-lingual and intra-lingual translation to convey their ideas to the masses. It needs to be seen that the translation in colonial times was a two way process that lacked balance. Colonizer's biased translation of the native's culture did an irreparable damage to the image of the Orient that persisted for long and could not be corrected until recently with the advent of the 'cultural turn'.

Postcolonial translation theorists offered a critique of the objectivity and transparency that traditional translation theorists claimed and began to dismantle the unequal power relations between an 'original' text and its translation. One of the most prominent studies that engage with the question of unequal power relations between cultures is Tejaswini Niranjana's book Siting Translation: History, PostStructuralism and the Colonial Context (1992). One of the primary aims of Niranjana is to deliberate upon by the construction of the colonial subject in literary translations. Many of her examples come from the context of Indian colonization. Through an extensive study of the works of colonial administrator-cum-translators (like William Jones, Macaulay, Charles Grant, etc.), Niranjana unfolds the systemic (mis)construction of the colonized subject (referred largely as

\footnotetext{
5 Macaulay argued: "I have no knowledge of either Sanskrit or Arabic...I have read translations of the most celebrated Arabic and Sanskrit works.... a single shelf of a good European library was worth the whole native literature of India and Arabia. The intrinsic superiority of the Western literature is indeed fully admitted by those members of the committee who support the oriental plan of education".
} 
Hindoo in her work) as submissive, indolent, lazy, deceitful, effeminate and what not. She writes: "Free acceptance of subjection is ensured, in part, by the production of hegemonic texts about the civilization of the colonized by philosophers like Hegel, historians like Mill, Orientalists like Sir William Jones. The scholarly discourses, of which literary translation is conceptually emblematic, help to maintain the dominance of the colonial rule that endorses them through the interpellation of its subjects" (Niranjana 1992: 11). For her, the relation between languages, cultures and races is that of asymmetry but there is a lack of awareness in contemporary translation theories about this asymmetry. She aims to engage with problematic of representation in colonial cultures because representation of these relations in literature tends to hide these inequalities. She perceives translation as a political activity and writes: "Translation as a practice shapes, and takes shape within, the asymmetrical relations of power that operate under colonialism" (Niranjana 1992: 2). Generally, the traditional theories of translation present the task of representation as innocent, objective and transparent. Niranjana performs a poststructuralist analysis of such theoretical assumptions so as to lay bare the politics underlying these notions of representation. She finds Derrida's notion of origin ${ }^{6}$ as an enabling paradigm in this regard. With its emphasis on the shifting nature of the origin, Derrida's theory could be used to critique the obsession of the classical translation theories about the original text as a 'pure' and 'transparent' entity. In the light of Derridian theory, it was possible to argue that all translations are re-presentation of an already existing representation. Translation, thus, involves not merely substitution but a complex process of re-writing. Niranjana

\footnotetext{
${ }^{6}$ For further understanding the structurality of structures and the notion of origin as an absent presence that allows the play of signification, refer to Derrida's essay "Structure, Sign and Play in the Discourse of Human Sciences".
} 
argues that the postcolonial translators can challenge the hegemonic version of colonial history by offering alternative images through the practice of double writing. Her strategies of translation allow the reader to visualize the constructed nature of both the original as well as the translation. She also draws upon Benjamin's theory of translation and the role played by translator. For Benjamin, translation accords perennial circulation and democratized proliferation of the source text. Translation is a part of the afterlife of the text that allows it to proliferate and acquire new meanings in the changing cultural contexts. In arguing for a critical reading of colonial translations via theories of deconstruction, Niranjana is reiterating the task of the translator as it was defined by Walter Benjamin (1969): "It is the task of the translator to release in his own language that pure language which is under the spell of another, to liberate the language imprisoned in a work in his re-creation of that work" (80). While she perceives these western theories as enabling paradigms to approach the multi-layered framework of translation, Indian scholars differ on this point. In the essay "A. K. Ramanujan's Theory and Practice of Translation", Vinay Dharwadker lambasts Niranjana for her incorrect critique of A.K. Ramajunan as it was based on manipulation of facts. In regard to this, Gentzler argues that this criticism is suggestive of growing dissatisfaction with the post-structuralist analysis of translation theory that she engages with. He writes: "The main issue seems to be a resistance to a new kind of western colonization, i.e., scholars educated in the west applying complex deconstructive strategies to translators from India without really understanding the traditions and forms of the source culture, nor the strategies that translators have used to convey those forms and ideas" (Gentzler 2010: 181). 
The second argument concerning the hierarchy between source text and the translated text has been taken up in great detail by Maria Tymoczko in the essay titled "Post-colonial Writing and Literary Translation". The major thrust of her argument is to negate the master-slave relationship between a text and its translation, which remained a dominant paradigm of understanding translation in colonial period. This she establishes by engaging with the different aspects of these two categories. She begins by talking about the notion of transposition. To translate is to transpose a text from one language to another. Postcolonial writing, on the other hand, entails transposing a culture with all its complexities. With recent developments in Translation Studies, it has been established that an act of translation does not mean a word-toword or sense-to-sense substitution. Rather, it is a transaction between two cultures that undergoes negotiation in the process of translation. On a similar note, she argues that both the translation as well as postcolonial writing aim to approximate the 'original' culture but attaining the perfect equivalence is impossible. She writes:

Another name for the choices, emphases and selectivity of both translators and postcolonial writers is interpretation. Judgment is inescapable in the process; 'objectivity' is impossible. And just as there can be no final translation, there can be no final interpretation of culture through a literary mode" (Tymoczko 1999: 24).

Even though Spivak also underlines the agency of the translator in the act of translation, she would partially disagree with this statement about approximation. In the essay "The Politics of Translation", she defines the role of a translator as one that involves intimacy with the source text. She argues: "The task of the translator is to facilitate this love between the original and its shadow, a love that permits fraying, holds the 
agency of the translator and the demands of her imagined or actual audience at bay" (Spivak 1993: 181). One can visualize the similarity of patterns in Tymoczko's formulation despite the apparent differences. Through a subtly drawn parallel between postcolonial literature and literary translation she arrives at the conclusion that "interlingual literary translation provides an analogue for postcolonial writing" (Tymoczko 1999: 20). A closer examination reveals that both the disciplines concern with similar anxieties, expectations and constraints. Hence, the role of the translator in postcolonial period is no less complex than that of the author.

Through the discussions above, one can visualize that there is an intricate relationship between politics and translation that was overlooked for a long time in the field of Translation Studies. To translate is to enter into the domain of the politics. The process involves making a choice at multiple levels. Moreover, what has to be said and how it has to be said also involves a conscious strategy on the part of the translator. Aditya Kumar Panda argues: "There is always a motivation behind a translation and its construction of meaning ... From the very act of selecting a text to interpret it in translation is a conscious deliberate process which cannot resist socio-cultural and political forces." Due to its political nature, translation plays a significant role in the formation of the literary canon. Even though the notion of a universal literary canon is a construct, one cannot deny the power play amid texts that are selected for circulation across the globe via translation. Different nation states make use of censorship if a work of art/literature sounds politically/aesthetically/culturally incorrect to the authorities. The issuance of fatwa calling death of Salman Rushdie for the novel The Satanic Verses (1988) is a case in point. While some texts are outrightly banned, few others are chosen for translation out of several potential 
'remarkable' texts. This speaks a lot about the politics involved in the process of canonization. The advent of the Globalization has only added to the complexities involved in the ways of assessing both canon formation and translation.

Countries across the world witnessed a downtrend in the economy during 1980s. This led them to reformulate their economic policies in favour of de-regularization. Under the rubric of New Economic Policy, India also had its share of economic reforms in early 1990s that emphasized Liberalization and Privatization. This period of liberal crosscultural exchange heralded the phase that is generally called Globalization. The economies of the world came closer and the entire world became a market. This is not to negate the neocolonial hierarchal relations between the developed and developing economies. It is the interplay between the dual forces of global market and the neocolonial power structures that define controls and operates the various disciplines of academia including Translation Studies.

One radical transformation in Translation Studies took place during the phase of decolonization when translation critics made an extensive use of Deconstruction theory. With the advent of Globalization, the category once again demanded a re-visitation of the early theories of translation in the wake of technological developments as well as market-centric publishing industry. Translation in the era of globalization becomes an act of collaboration amongst multiple stakeholders. The interplay between the author and the translator has extended its domain to include the editor, publisher, illustrator, market analyst and distributor. This notion is further complicated in the presence of new translational practices like machine translation, fansnubbing and interpretation of hypertexts. One can immediately realize that there is an exponential increase in the complexities 
involved in the process of translation as well as the role of the translator. There is an increased pressure on the translator to cater to the demands of publishing industry, which in turn, caters to the market forces of demand and supply. One can conclude that despite the efforts of the postcolonial translation theory to liberate the translator from being tied down to the original and allow him to use his creative faculties without turning an infidel to the source text, the relative freedom of the translation has decreased in the postcolonial situations.

\section{References}

BASSNETT, SUSAN. 1980. Translation Studies. London: Methuen.

BASSNETT, SusAN. 1998. The Translation Turn in Cultural Studies. Constructing Cultures. ed. by Susan Bassnett and Andrě Lefevere. Clevedon. England: Multilingual Matters. 123-140.

BASSNETT, SuSAN.; and ANDRĔ LEFEVERE. 1990. Translation, History and Culture. London: Pinter.

BENJAMIN, WALTER. 1969. Illuminations. tr. by Harry Zohn. New York: Schocken Books. 69-82.

FouCAUlt, Michel. 1998. What is an Author?. Aesthetics, Methods and Epistemology. ed. by James D. Faubion. New York: The New Press. 205-222.

GentZleR, EDWIN. 2010. Contemporary Translation Theories. New Delhi, India: Viva Books.

YounG, G. M. (ed.). 1967. Indian Education (Minute of the 2nd of February, 1835). Macaulay, Prose and Poetry. Cambridge: Harvard University Press.

Niranjana, Tejaswini. 1992. Siting Translation: History, PostStructuralism and the Colonial Context. California: University of California Press.

Panda, Aditya Kumar. 2013. "Politics and Translation". The Criterion: An International Journal in English 4(2). Retreived from http://www.the-criterion.com/V4/n2/Aditya.pdf 
Pratibha Kumari

Prasad, G. J. V. 2010. Introduction. Translation and Culture. ed. by GJV Prasad. New Delhi, India: Pencraft International. 11-18.

SPIVAK, GAYATRI CHAKRAVORTI. 1993. The Politics of Translation. Outside in the Teaching Machine. New York: Routledge. 170-200.

TYMOCZKO, MARIA. 1999. Postcolonial Writing and Literary Translation. Post-Colonial Translation: Theory and Practice. ed. by Susan Bassnett and Harish Trivedi. London: Routeledge. 19-40. 